Research article

\title{
Secretion of functional human enzymes by Tetrahymena thermophila
}

\author{
Thomas Weide $^{\dagger 1}$, Lutz Herrmann ${ }^{\dagger 1}$, Ulrike Bockau ${ }^{1,2}$, Nadine Niebur ${ }^{1,2}$, \\ Ingo Aldag ${ }^{1}$, Wouter Laroy ${ }^{3}$, Roland Contreras ${ }^{3}$, Arno Tiedtke ${ }^{2}$ and \\ Marcus WW Hartmann*1,2
}

Address: ${ }^{1}$ Cilian AG, Johann-Krane-Weg 42, D-48149 Münster, Germany, ${ }^{2}$ Institut für allgemeine Zoologie und Genetik, Universität Münster, Schlossplatz 5, D-48149 Münster, Germany and ${ }^{3}$ Department of Molecular Biology Research, Unit for Fundamental and Applied Molecular Biology, Ghent and Flanders Interuniversity Institute for Biotechnology, Technologiepark 927, B-9052 Ghent, Belgium

Email: Thomas Weide -weide@cilian.de; Lutz Herrmann - herrmann@cilian.de; Ulrike Bockau - bockau@cilian.de; Nadine Niebur - niebur@cilian.de; Ingo Aldag - aldag@cilian.de; Wouter Laroy -Wouter.Laroy@dmbr.UGent.be; Roland Contreras - Roland.Contreras@dmbr.UGent.be; Arno Tiedtke - tiedtke@uni-muenster.de; Marcus WW Hartmann* - hartmann@cilian.de

* Corresponding author †Equal contributors

Published: 16 March 2006

BMC Biotechnology2006, 6:19 doi:10.1 186/1472-6750-6-19
Received: 15 September 2005

Accepted: 16 March 2006

This article is available from: http://www.biomedcentral.com//472-6750/6/19

(C) 2006Weide et al; licensee BioMed Central Ltd.

This is an Open Access article distributed under the terms of the Creative Commons Attribution License (http://creativecommons.org/licenses/by/2.0), which permits unrestricted use, distribution, and reproduction in any medium, provided the original work is properly cited.

\begin{abstract}
Background: The non-pathogenic ciliate Tetrahymena thermophila is one of the best-characterized unicellular eucaryotes used in various research fields. Previous work has shown that this unicellular organism provides many biological features to become a high-quality expression system, like multiplying to high cell densities with short generation times in bioreactors. In addition, the expression of surface antigens from the malaria parasite Plasmodium falciparum and the ciliate Ichthyophthirius multifilis suggests that $T$. thermophila might play an important role in vaccine development. However, the expression of functional mammalian or human enzymes remains so far to be seen.
\end{abstract}

Results: We have been able to express a human enzyme in $T$. thermophila using expression modules that encode a fusion protein consisting of the endogenous phospholipase $A_{1}$ precursor and mature human DNasel. The recombinant human enzyme is active, indicating that also disulfide bridges are correctly formed. Furthermore, a detailed $\mathrm{N}$-glycan structure of the recombinant enzyme is presented, illustrating a very consistent glycosylation pattern.

Conclusion: The ciliate expression system has the potential to become an excellent expression system. However, additional optimisation steps including host strain improvement as wells as measures to increase the yield of expression are necessary to be able to provide an alternative to the common $E$. coli and yeast-based systems as well as to transformed mammalian cell lines.

\section{Background}

Throughout the last decades the ciliate Tetrahymena thermophila has been used as the model system of choice in many areas of molecular, cell and developmental biology [1-4]. For example milestone discoveries like ribozymes that enable RNA-mediated catalysis [5], the basic analysis 
of dynein motors [6], the finding of telomeres and telomerases $[7,8]$ and the function of histone acetyltransferases in transcription were made in Tetrahymena. Very recently, the discovery of small scan RNA elucidates the role of RNAi mediated genome rearrangement [9].

In previous experiments $T$. thermophila has been used to express proteins of two phylogenetic closely related alveolate species. Gaertig et al. showed expression of the I-antigen of the ciliate Ichthyophthirius multifiliis, a parasite that causes the white spot disease of freshwater fish $[10,11]$. Later on it could be demonstrated that the GPI-anchored circumsporozoite (CS) protein of the malaria parasite Plasmodium falciparum, was expressed and targeted to the surface of $T$. thermophila. Consequently, $T$. thermophila could also play an important role in strategies for vaccine development [12]. All three protozoans Tetrahymena thermophila, Ichthyophthirius multifiliis as well as the malaria parasite Plasmodium falciparum belong to the alveolates, a distinct phylogenetic group that includes ciliates, apicomplexans and dinoflagellates. They are characterised by both very AT-rich genomes and an unusual codon usage [13-16]. However, so far the expression of functional mammalian or human proteins in $T$. thermophila remains to be shown.

The T. thermophila genome has just been completely sequenced by an NIH program and can now be used for thorough proteome analysis (The Institute for Genomic Research [17]). Furthermore, it is known that T. thermophila cells grow fast to high cell densities in inexpensive media and simple bioreactor infrastructure $[18,19]$. Overall, these are the basis for developing an excellent expression system and using the ciliate $T$. thermophila for biotechnology applications [20]. In contrast to the previously done expression experiments here we report for the first time the heterologous expression of a human enzyme that subsequently is secreted into the surrounding medium.

We selected the human DNasel to demonstrate that $T$. thermophila as an expression host is able to produce functional human enzymes. Human DNase I is a $29.3 \mathrm{kD}$ glycoprotein with two $\mathrm{N}$-glycosylation sites at $\mathrm{Asn}_{18}$ and Asn $_{106}$ and two calcium ion binding sites. One of two intrachenar disulfide bridges $\left(\mathrm{Cys}_{101} / \mathrm{Cys}_{104}\right.$ and $\mathrm{Cys}_{173} /$ $\mathrm{Cys}_{209}$ ) is crucial for enzyme activity [21]. Aging of the beta-sandwich shaped enzyme is accompanied by deamidation of $A n_{74}$ thereby reducing enzyme activity and facilitating degradation of the protein [22]. Interestingly, recombinant human DNase I produced in CHO cells (Pulmozyme ${ }^{\varpi}$, Roche) is administered to patients with cystic fibrosis by inhalation in order to reduce sputum viscoelasticity and to improve lung function.

\section{Results \\ Expression and secretion of functional human DNase I by T. thermophila}

Aim of this study was to show that T. thermophila is capable of expressing a human enzyme which is secreted under the control of an endogenous T. thermophila derived precursor peptide. The codon bias of ciliates has been analysed in detail $[13,15,16]$. In summary it is quite different from human genes. 15 of the 63 possible codons in human DNase I are very rare codons in T. thermophila according to the definition of Wutschick and Karrer: A rare codon is a codon that is no more than $10 \%$ of the total and less than $50 \%$ of the fraction expected if all synonyms are used at equal frequency. As an example, codons that encode arginine illustrate this problem. From six possible codons only AGA is preferentially used in highly expressed genes $(96 \%)$ in $T$. thermophila. The other five codons AGG, CGA, CGC, CGG and CGU are only used in less than $5 \%$ of the total arginine codons and especially the CGG codon is very rare. The original human DNaseI sequence (accession number: NM_005223) consists of 14 arginines, but only two of the human original codons are optimal for expression in the T. thermophila host system. As both groups Wutschick and Karrer as well as Larsen et al. report a correlation between frequently used codons and a higher expression level of genes that contain these codons we used a synthetic "codon-adapted" DNaseI gene to avoid problems in expression.

The synthetic optimised gene encodes the human 282 amino acids (aa) of the human precursor of DNase I (accession number: DQ073047). In summary 67\% of all codons (188 of 282) were changed into codons that are frequently used in T. thermophila. From the 188 optimised codons more than 50\% (97 of 188) are changed at the third position. Only one third (93 of 282) of the original sequence seemed to be suitable to express a human enzyme in the ciliate. The original human DNase I cDNA and the codon adapted sequence are compared in figure 1. In our experiments we want to express and secrete the human DNaseI by a ciliate system. Therefore we constructed expression cassettes that encode parts of the precursor sequence of the $\mathrm{PLA}_{1}$ (phospholipase $\mathrm{A}_{1}$ ) gene (accession number: AJ508393) and the mature human DNaseI (aa 23 to 281) of the synthetic gene [23]. The PLA prepro-peptide has significant similarity to members of the cathepsin L family and mediates secretion into the medium [24]. We have previously characterized the cleavage site between the pro-peptide and the mature enzyme to be between aa 110 and 111 by sequencing of the N-terminus of the mature PLA $A_{1}$ enzyme (unpublished data). The first fusion protein encodes the $\mathrm{PLA}_{1}$ signal peptide as determined by SignalP [25] (aa 1-23 of PLA ${ }_{1}$ ), an additional 13 amino acid spacer (aa 24-36 of PLA $_{1}$ ) and the mature DNaseI (aa 23 to 281 encoded by the synthetic 
WT

ATg AgG GgC ATg AAg CTG CTG GGg GCG CTG CTG GCA CTG GCG GCC CTA CTG CAg GGg GCC ATG AGA GGT ATG AAG TTG CTC GGT GCT TTA TTA GCC CTT GCT GCT CTT TTA TAA GGT GCT $\begin{array}{llllllllllllllllllll}M & R & G & M & K & \text { L } & \text { L } & \text { G } & \text { A } & \text { L } & \text { L } & \text { A } & \text { L } & \text { A } & \text { A } & \text { L } & \text { L } & \text { Q } & \text { G } & \text { A }\end{array}$

GTG TCC CTG AAg ATC GCA GCC TTC AAC ATC CAG ACA TTT GGG GAG ACC AAg Atg tCC AAT GTT TCC TTA AAG ATC GCT GCT TTC AAC ATC CAA ACT TTC GGT GAA ACT AAg ATG TCT AAC $\begin{array}{lllllllllllllllllllll}\mathrm{V} & \mathrm{S} & \mathrm{L} & \mathrm{K} & \mathrm{I} & \mathrm{A} & \mathrm{A} & \mathrm{F} & \mathrm{N} & \mathrm{I} & \mathrm{Q} & \mathrm{T} & \mathrm{F} & \mathrm{G} & \mathrm{E} & \mathrm{T} & \mathrm{K} & \mathrm{M} & \mathrm{S} & \mathbf{N}\end{array}$

GCC ACC CTC GTC AGC TAC ATT GTG CAG ATC CTG AGC CGC TAT GAC ATC GCC CTG GTC CAG GCT ACC CTC GTT TCT TAT ATC GTC CAA ATT CTC TCC AGA TAT GAT ATT GCT CTC GTC TAA $\begin{array}{llllllllllllllllllll}\mathrm{A} & \mathrm{T} & \mathrm{L} & \mathrm{V} & \mathrm{S} & \mathrm{Y} & \mathrm{I} & \mathrm{V} & \mathrm{Q} & \mathrm{I} & \mathrm{L} & \mathrm{S} & \mathrm{R} & \mathrm{Y} & \mathrm{D} & \mathrm{I} & \mathrm{A} & \mathrm{L} & \mathrm{V} & \mathrm{Q}\end{array}$ GAG GTC AGA GAC AGC CAC CTG ACT GCC GTG GGG AAG CTG CTG GAC AAC CTC AAT CAG GAT

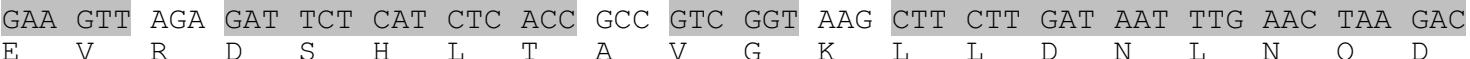
GCA CCA GAC ACC TAT CAC TAC GTG GTC AGT GAG CCA CTG GGA CGG AAC AGC TAT AAg GAG GCT CCC GAT ACC TAT CAC TAC GTC GTC TCT GAA CCC TTG GGT AGA AAC TCT TAT AAG GAA $\begin{array}{llllllllllllllllllll}\mathrm{A} & \mathrm{P} & \mathrm{D} & \mathrm{T} & \mathrm{Y} & \mathrm{H} & \mathrm{Y} & \mathrm{V} & \mathrm{V} & \mathrm{S} & \mathrm{E} & \mathrm{P} & \mathrm{L} & \mathrm{G} & \mathrm{R} & \mathrm{N} & \mathrm{S} & \mathrm{Y} & \mathrm{K} & \mathrm{E}\end{array}$ CGC TAC CTG TTC GTG TAC AGG CCT GAC CAG GTG TCT GCG GTG GAC AGC tAC TAC TAC GAT AGA TAC TTA TTC GTT TAC AGA CCC GAC CAA GTC TCT GCT GTC GAT TCC TAC TAC TAT GAT

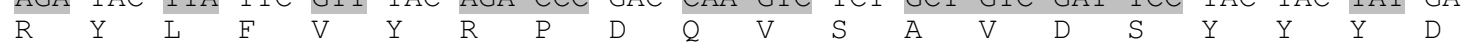
GAT GGC TGC GAG CCC TGC GGG AAC GAC ACC TTC AAC CGA GAG CCA GCC ATT GTC AGg TTC GAT GGT TGC GAA CCT TGC GGT AAT GAT ACC TTC AAC AGA GAA CCT GCC ATC GTT AGA TTC

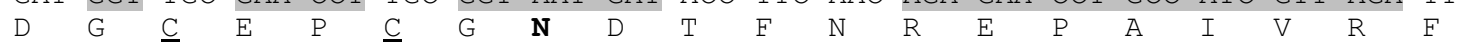
TTC TCC CGg TTC ACA GAg GTC AGg GAG TTT GCC ATT GTT CCC CTG CAT GCG GCC CCG GGG TTC TCT AGA TTC ACC GAA GTC AGA GAA TTC GCT ATC GTC CCC TTA CAC GCT GCC CCC GGT $\begin{array}{llllllllllllllllllll}\mathrm{F} & \mathrm{S} & \mathrm{R} & \mathrm{F} & \mathrm{T} & \mathrm{E} & \mathrm{V} & \mathrm{R} & \mathrm{E} & \mathrm{F} & \mathrm{A} & \mathrm{I} & \mathrm{V} & \mathrm{P} & \mathrm{L} & \mathrm{H} & \mathrm{A} & \mathrm{A} & \mathrm{P} & \mathrm{G}\end{array}$

GAC GCA GTA GCC GAG ATC GAC GCT CTC TAT GAC GTC TAC CTG GAT GTC CAA GAG AAA TGG GAC GCC GTT GCT GAA ATC GAT GCT TTG TAC GAT GTT TAC CTC GAT GTC CAA GAA AAG TGG

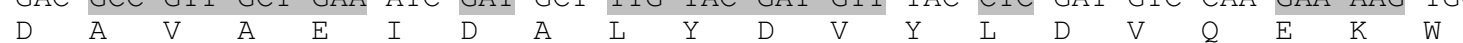

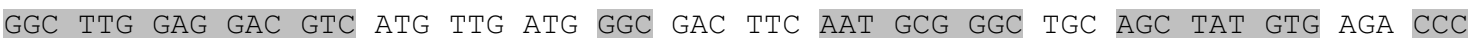
GGT CTC GAA GAT GTT ATG TTG ATG GGT GAC TTC AAC GCT GGT TGC TCC TAC GTT AGA CCT $\begin{array}{llllllllllllllllllll}\text { G } & \text { L } & \text { E } & \text { D } & \text { V } & \text { M } & \text { L } & \text { M } & \text { G } & \text { D } & \text { F } & \text { N } & \text { A } & \text { G } & \underline{C} & \text { S } & Y & \text { V } & \text { R } & P\end{array}$ TCC CAG TGG TCA TCC ATC CGC CTG TGG ACA AGC CCC ACC TTC CAG TGG CTG ATC CCC GAC TCT CAA TGG TCC TCC ATC AGA TTG TGG ACT TCC CCC ACT TTC CAA TGG TTA ATT CCT GAT AGC GCT GAC ACC ACA GCT ACA CCC ACG CAC TGT GCC TAT GAC AGG ATC GTG GTT GCA GGG TCC GCT GAT ACC ACT GCT ACC CCC ACT CAC TGT GCC TAC GAT AGA ATT GTC GTC GCT GGT

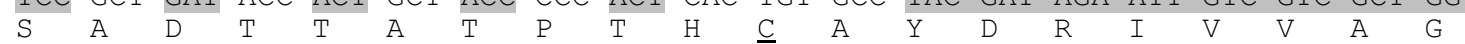
ATG CTG CTC CGA GGC GCC GTT GTT CCC GAC TCG GCT CTT CCC TTT AAC TTC CAG GCT GCC ATG CTT CTC AGA GGT GCC GTC GTC CCC GAC TCC GCT CTT CCC TTC AAC TTC CAA GCT GCT $\begin{array}{llllllllllllllllllll}M & \mathrm{~L} & \mathrm{~L} & \mathrm{R} & \mathrm{G} & \mathrm{A} & \mathrm{V} & \mathrm{V} & \mathrm{P} & \mathrm{D} & \mathrm{S} & \mathrm{A} & \mathrm{L} & \mathrm{P} & \mathrm{F} & \mathrm{N} & \mathrm{F} & \mathrm{Q} & \mathrm{A} & \mathrm{A}\end{array}$

TAT GGC CTG AGT GAC CAA CTG GCC CAA GCC ATC AGT GAC CAC TAT CCA GTG GAG GTG ATG TAC GGT CTT TCC GAC TAA CTC GCT CAA GCC ATT TCT GAC CAC TAC CCT GTC GAA GTC ATG

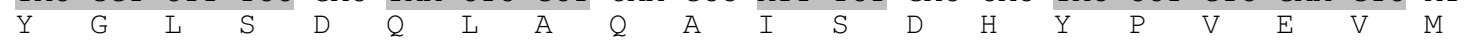

CTG AAG TGA TTG AAG TGA $\mathrm{L} \quad \mathrm{K} \quad-$

\section{Figure I}

Codon adaptation of the used synthetic DNase I gene. As the codon bias of $T$. thermophila is different from that of human genes $67 \%$ of 283 coding triplets of the original human codons (WT) were changed into codons that are known to be mostly present in highly expressed T. thermophila genes $(\mathrm{CO})[13,16]$. The adapted codons are marked by gray boxes. The corresponding amino acid sequence is given in single letter code; $\mathrm{N}$-glycosylation sites are highlighted in bold letters, cysteines forming disulfide bridges are underlined. 
a Structure of expression cassettes

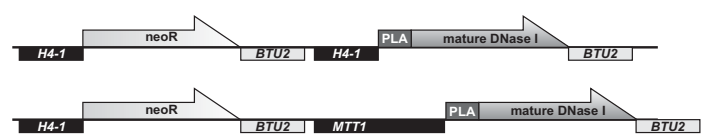

b Influence of glycosylation on serum avidity

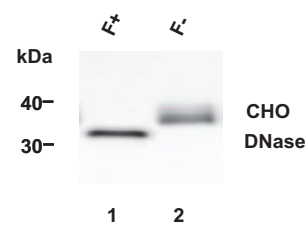

d Activity of rhDNase I

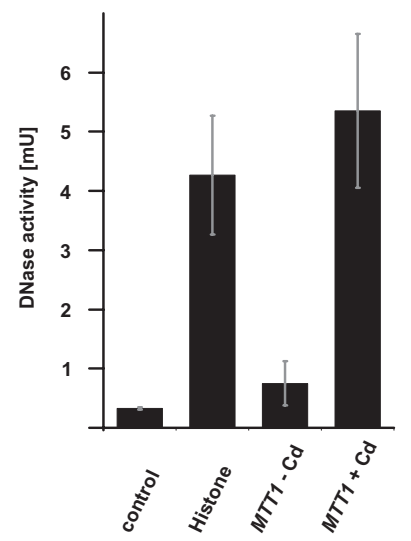

f Up-scalability of cultivation

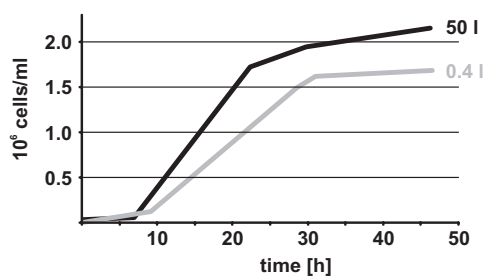

\section{Figure 2}

Expression of functional human DNasel. a: The structure concept of the expression cassettes. For all expression cassettes we used the cell-cycle dependent H4-I histone or the Cd-inducible MTTI promotor and the beta tubulin 2 (BTU2) terminator sequence. Selection was done by the neo resistance gene (neoR). Secretion of the rhDNase was regulated by parts of the endogenous precursor of PLA . We used the first 36, II 0 and II 5 amino acids of the PLA-precursor. The mature human DNase I corresponds to the aa 23-28I. b: We obtained an anti DNasel serum by using CHO derived DNase I (Pulmozyme) as an antigen. After that the serum was tested by western blot using de-glycosylated DNasel (PNGaseF treated, F+ lanel) as well as the glycosylated protein. No significant difference in the signal strength could be observed, suggesting that the $\mathrm{N}$-glycan structure of rhDNase has no, or only a minor influence on the avidity of the serum. c: Secretion of processed recombinant human DNasel into the media. Lane I: $20 \mu$ l supernatant of the T. thermophila wildtype strain BI868.7, negative control; Lane2: $20 \mu$ l supernatant of mock-(EGFP) transformed T. thermophila; Lane 3-5: $20 \mu$ l supernatant of T. thermophila cells that were transformed with expression plasmids, carrying the spPLA ${ }_{36}$, PPPLA $_{110}$ and PPPLA 115 Prepro-peptides, respectively. d: Determination of DNase activity in $10 \mu \mathrm{l}$ supernatant of transformed T. thermophila. Control: mock-(EGFP) expressing cells; Histone: cell cycle dependent expression of PPPLA ${ }_{115} ; M T T I$ : inducible expression of PPPLA ${ }_{115} ;(M T T I-C d$ : non-induced; $M T T I+C d$ : induced). e: Different amounts of rhDNasel from CHO cells (I.0, 2.5 and $5.0 \mathrm{ng}$ ) were used to roughly quantify the yield of rhDNase in $30 \mu \mathrm{lpPLA}_{115}$ supernatant of $T$. thermophila. f: Demonstration of up-scalability by comparing cell titres during 50 litre fermentation (black) and $400 \mathrm{ml}$ shaker flask cultivation (gray) of rhDNase I secreting T. thermophila. 
gene). The second hybrid protein consists of the whole prepro-peptide of $\mathrm{PLA}_{1}$ (aa 1-110) and the mature DNaseI. The third cassette is similar to the second except for the first five amino acids of the secreted mature PLA ( sin- $^{2}$ gle letter code GEATE; aa 111-115). This cassette was made to ensure an optimal cleavage of the proPLA ${ }_{1}$-DNaseI fusion protein by endogenous pro-peptidases. The expression cassettes were cloned into the $\mathrm{pH} 4 \mathrm{~T} 2$ vector that consists of two rDNA origins and the neomycin resistance gene (neoR) [26]. Both the neoR gene and the PLA ${ }^{-}$ DNasehybrid genes were controlled by the cell-cycle dependent histone promoter $\mathrm{H} 4-1$ and the beta tubulin 2 BTU2 terminator (Figure 2a). We transformed conjugating $T$. thermophila with the expression plasmids by electroporation, and monitored the successful transformation by selection against paromomycin. Supernatants of the different cultures were analysed by SDS-PAGE and Western blot for secretion of the recombinant human DNaseI (rhDNaseI). All samples analysed expressed and secreted rhDNaseI, regardless of the length of the PLA $\mathrm{PL}_{1}$-prepropeptide sequence fused to the DNaseI (Figure 2c). Furthermore, all expression modules resulted in rhDNaseI proteins of the same size ( $35 \mathrm{kD}$ ), indicating the existence of a processing mechanism that is independent of a conserved pro-peptidase recognition site, similar to the known processing of granule lattice proteins of dense core vesicles in T. thermophila [27]. A control strain that expresses and secretes EGFP and the non-transformed $T$. thermophila wild type strain B1868.7 was used. Supernatants of cells expressing the ppPLA 115 -DNase fusion protein were assayed for DNase activity. Compared to supernatants of mock-transformed cells a significantly elevated enzyme activity was measured. The heterologous expression of human DNaseI by T. thermophila was also analysed by application of the inducible metallothionein1 promoter (MTT1) system [28] (Figure 2d). In these experiments the expression of the ppPLA ${ }_{115}$-DNase fusion protein was regulated by the addition of Cadmium to the medium. The induced cells exhibited a significantly elevated DNase activity in the supernatant. In non-induced cultures the DNase activity remained - just like expected - close to the basal level. This clearly argues that the observed increased DNaseI activity in the supernatant is due to the secretion of functional rhDNase, confirming the experiments shown in Figure 2c. The basal activity measured in the negative control corresponds to at least two endogenous DNases (data not shown). As rhDNase combines in one enzyme all assets necessary for development of a novel expression system with secretion, disulfide bridge formation and glycosylation site recognition the main focus of our initial experiments was to illustrate that not only antigens from related species ( $I$. multifiliis and $P$. falciparum) but also functional human enzymes of biotechnological interest can be expressed and secreted by the ciliate system. Nevertheless, to give a first and roughly estimation of the yield of secreted rhDNase we used semi-quantitative Western blotting. Therefore we generated a polyclonal antiserum against the rhDNaseI from $\mathrm{CHO}$ cells and tested first if the $\mathrm{N}$-glycosylation has an impact on avidity. Figure $2 \mathrm{~b}$ clearly illustrates that both glycosylated DNaseI as well as the de-glycosylated enzyme display the same signal strength in Western blot analysis, suggesting that almost all of the antigenic epitopes recognised are on protein level and that the N-glycan structure plays an unimportant role in avidity. This allows us to give a first and rough estimation about the amount of the secreted DNaseI, by semi-quantitative Western blotting. We found ca. $100 \mu \mathrm{g}$ rhDNase per litre supernatant fluid (see Figure $2 \mathrm{e} ; 1 \mathrm{ng} / 10 \mu \mathrm{l}$ supernatant). This crudely estimated amount combined with the determined DNase activity of $400 \mathrm{U}$ per litre supernatant $(4 \mathrm{mU} / 10 \mu \mathrm{l}$, see Figure 2d) means that a "specific" activity can be determined as ca. 4 Units per $\mu \mathrm{g}$ rhDNase. For most biotechnical applications it is crucial to obtain a first impression whether or not the cultivation of transformants can be scaled up. Therefore we tested if the rhDNA secreting clone is growing in the same way as previously described for wildtype strains $[20,29]$. RhDNase I expressing cells were grown on a small scale ( $400 \mathrm{ml}$ shaker flask), as well as in 2 and 50 litre batch fermentations. Figure $2 \mathrm{f}$ illustrates that growth (up to more than $2 \times 10^{6} \mathrm{cells} / \mathrm{ml}$ ) of transformants is independent of the culture volume. Furthermore up-scaling does not alter results shown in Figure $2 b-d$.

\section{Glycosylation pattern on recombinant proteins derived from $T$. thermophila}

Transport through the ER and Golgi compartments usually is accompanied by the addition of N-glycans. We addressed this point for the recombinant DNaseI and performed band-shift assays by applying $\mathrm{N}$-glycosidase $\mathrm{F}$ (PNgase F) to immunoprecipitated DNaseI from supernatant of transformed T. thermophila cells (Figure 3a). An aliquot of this IP sample $(\mathrm{F}+)$ revealed a significant bandshift on a $15 \%$ SDS-gel when compared to the control without N-glycosidaseF treatment (F-). Glycosylated and de-glycosylated DNaseI from CHO cells was used as control. The significant reduction of the molecular weight of secreted rhDNaseI from $T$. thermophila demonstrates that the DNase becomes glycosylated while shuttling through the ER and Golgi. Furthermore comparison of lane 3 and 5 also shows that the non-glycosylated rhDNase from $T$. thermophila and CHO-cells are running at heights of comparable molecular weight. Next we applied a Concanavalin A (Con A) pulldown assay to test whether the glycans of secreted rhDNaseI are terminated by N-terminal mannoses, as described for endogenous secreted enzymes of Tetrahymena [30,31]. We used the same cell-free supernatants as in the IP approach (compare Figure 3a lane 4 and 5). The B1868.7 wildtype supernatant spiked with glyco- 


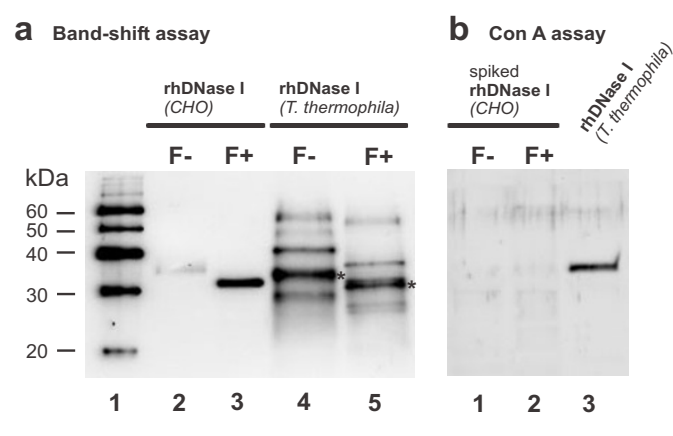

C N-glycan analysis of $T$. thermophila rhDNase I

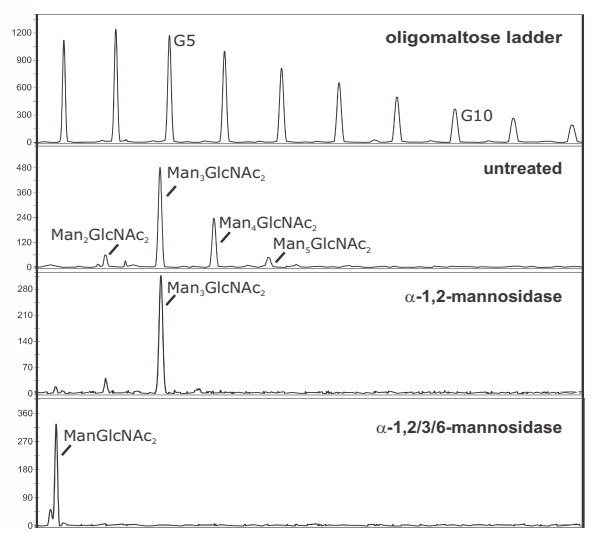

d N-glycan analysis of CHO rhDNase I

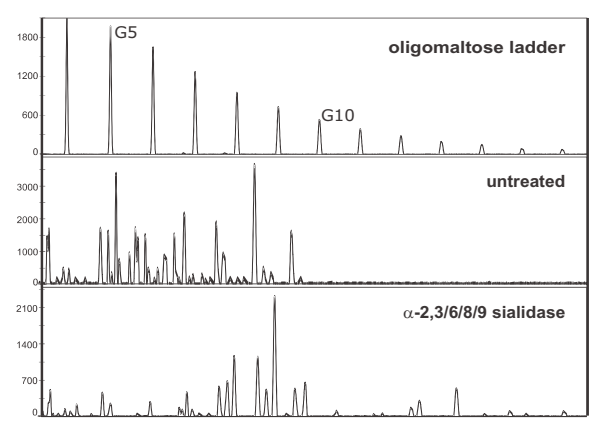

\section{Figure 3}

N-glycan structure on recombinant secreted human DNase I. a: Band-shift assay: rhDNase I from CHO cells and secreted rhDNase I from $T$. thermophila were de-glycosylated. The treatment with PNGase $F(F+)$ results in a significant bandshift, when compared to the controls (F-), illustrating that the secreted rhDNase I of $T$. thermophila becomes glycosylated. As $T$. thermophila rhDNase I had been concentrated by immunoprecipitation, additional bands of antibody-chains appear in Western blotting. The DNase signals are highlighted by asterisks. b: Concanavalin A pulldown assay: Supernatants of transformed T. thermophila strain and a wildtype strain (B 1868.7) were analysed. The supernatant of the wildtype was spiked with equal amounts $(2 \mu \mathrm{g})$ of glycosylated $(\mathrm{F}-)$ or de-glycosylated $(\mathrm{F}+)$ rhDNase I from $\mathrm{CHO}$ cells, respectively. Only mannose-terminated glycosylated rhDNase is recovered by Con $A$ (lane 3 ), glycosylated (F-) and de-glycosylated rhDNase I (F+) from $\mathrm{CHO}$ cells did not bind to ConA beads (lanes I and 2). c: DSA-FACE N-glycan analysis of T. thermophila rhDNase I: This data illustrates the highly consistent $\mathrm{N}$-glycan structure on rhDNasel produced in $\mathrm{T}$. thermophila. All $\mathrm{N}$-glycans are mannose terminated, as shown by digestion with jack bean mannosidase in the lower panel. The most prominent structure is the $\mathrm{Man}_{3} \mathrm{GlcNAc}_{2}$ core pattern with additional alpha I,2 bound mannoses (two middle panels). d: DSA-FACE N-glycan analysis of CHO rhDNase I: On the CHO derived rhDNase I more than 20 distinct peaks, each corresponding to a different $\mathrm{N}$-glycan, are observed in the untreated sample. This typical complex profile of mammalian cells is in sharp contrast to the consistent $T$. thermophila glycosylation. Even removal of terminal $\mathrm{N}$-acetylneuraminic acid by treatment with sialidase still leads to a large number of various glycans (lower panel). 
sylated and de-glycosylated rhDNaseI from CHO cells was used as control. We added ConA beads and performed extensive washes, to avoid unspecific binding. Only the rhDNaseI from T. thermophila was recovered by the ConA beads, indicating that it predominantly contains $\alpha$-Dmannose terminated glycosylation chains. The DNaseI from $\mathrm{CHO}$ cells which contains a different, complex N-glycan feature with terminal galactose, $\mathrm{N}$-acetylglucoseamine or sialic acid residues and the de-glycosylated rhDNasel did not bind to the ConA (Figure $3 \mathrm{~b}$ ). The specificity of the ConA pulldown assays was nicely confirmed by the DSAFACE technology for N-glycan profiling [32]: These results illustrate that almost all recombinant protein displays a mannose terminated oligo-glycosylation pattern, comparable to endogenous secreted proteins [30]. The most prominent $\mathrm{N}$-glycan is the $\mathrm{Man}_{3} \mathrm{GlcNAc}_{2}$ structure (Figure. 3c). All structures can be reduced to ManGlcNAc using an unspecific mannosidase, indicating the presence of mannose only at the core. Overall the T. thermophila pattern is very consistent (see Figure 3c, second panel). This consistency is even more obvious when compared to the typical complex glycosylation of rhDNase I from $\mathrm{CHO}$ cells shown in Figure 3d (see second and third panel).

\section{Discussion}

Here we report for the first time the expression and secretion of functional human DNaseI, illustrating that not only surface proteins from related species but also mammalian proteins are potential candidates. To avoid problems in expression due to the fact that the codon bias in $T$. thermophila is quite different to that of mammalian cells we used a codon adapted gene in which critical triplets were changed (see figure 1). All hybrid constructs used lead to expression of the rhDNaseI in T. thermophila. These results clearly show that the here presented ciliate system has the high potential to become an attractive alternative for expression and secretion of complex functional human proteins. Furthermore, unlike in yeast expression systems, where hyper-glycosylation causes problems on recombinant proteins, the rhDNase secreted by $T$. thermophila carries a consistent, oligo-glycosylated N-glycan structure [33,34]. Additionally, the predominant $\mathrm{Man}_{3} \mathrm{GlcNAc}_{2}$ sequence on $T$. thermophila derived proteins could be an interesting starting point for in vitro glycosylation to produce homogenous glycoproteins. A well known problem of bacterial expression systems is the proper formation of disulfide bridges. As the expression and secretion of rhDNase I in the free-living protozoan $T$. thermophila yields a highly active enzyme, at least the required internal disulfide bridge $\left(\mathrm{Cys}_{173}-\mathrm{Cys}_{209}\right)$ must have formed in the right manner [21].

\section{Conclusion}

The roughly estimated yield of $100 \mu \mathrm{g} / \mathrm{L}$ rhDNase I in $T$. thermophila is a promising starting point for further improvements of this very young expression system. Established and commonly known systems surely currently have higher expression rates (e.g. $5 \mathrm{mg} / \mathrm{l} \mathrm{rhDNaseI}$ in COS-cells [35]). Yet there are other criteria to be met for a new expression host to be adopted by the biotech industry like up scalability, simple and inexpensive media, growing to high cell densities, protease-deficiency and ease of cell line engineering of the production strains that all contribute to low cost of manufacturing. In $T$. thermophila these requirements can be fulfilled because a simple bioreactor infrastructure is sufficient for production. Moreover, high cell density fermentation with cell retention is available in our laboratories $[18,29]$. The use of such techniques allows us to obtain cell densities in inexpensive media of more than $2.2 \times 10^{7}$ cells $/ \mathrm{ml}$, equivalent to $48 \mathrm{~g}$ dry weight, thereby reducing the cost of manufacturing. Genetic tools are at hand to increase promoter activity and to improve strains easily by targeted knock outs of proteases, random mutagenesis and secretion optimisation. These measures will lead to an excellent expression-secretion system bearing a competitive alternative to the common and technically mature systems like E. coli, yeast and transformed mammalian cell lines.

\section{Methods}

\section{Strains, cultivation and fermentation}

Tetrahymena thermophila strains B1868.4, B1868.7 and B 2068.1 were kindly provided by Peter J. Bruns and cultivated in skimmed milk medium $(2 \%$ skimmed milk, $0.5 \%$ yeast extract, $0.1 \%$ ferrous sulphate chelate solution and $1 \%$ glucose) on a Braun Certomat BS- 1 at $80 \mathrm{rpm}$ and $30^{\circ} \mathrm{C}$. For fermentations a Braun UD50 (50 litre) and Bioengineering KLF2000 (2 litre) equipped with standard Rushton impellers were used. Stirrer speed was limited to 300 and $400 \mathrm{rpm}$ respectively; $\mathrm{pO}_{2}$ was set to $25 \%$.

\section{Generation and transformation of expression plasmids}

Transformation of cells was performed with plasmids derived from the pH4T2 vector [26]. For the Cd-inducible expression the histone promoter in the $\mathrm{ppPLA}_{115^{-}}$construct was substituted by the T. thermophila MTT1-promoter. Metallothioneins, that are upregulated upon stress, are metal binding proteins playing a role in detoxification of the cell. In Tetrahymena the MTT1-promoter can be induced best by the addition of Cadmium [28]. Cloning of the expression modules and mutagenesis were performed with standard techniques. To ensure a translation of the fusion proteins a synthetic, codon optimised human DNaseI gene was used $[13,15]$. The synthesis was performed by a solid phase process described in German Patent DE 19812103.2 by the company ATG biosynthetics, Merzhausen Germany. In brief oligonucleotides were specifically annealed $3^{\prime}$ at the immobilized single stranded DNA and extended by a polymerase. A double strand-specific 5 ' nuclease digestion enables subsequent 
annealing of a new primer 3' at the growing synthetic gene and the cycle starts over. The sequence has been submitted to genbank (Accession number: DQ073047).

\section{Generation of polyclonal anti human DNase I antibodies from rabbit}

Recombinant human DNaseI from CHO cells (Pulmozyme $^{\circledast}$, Roche) was used to generate a specific antiserum from rabbit against human DNaseI. Affinity purification using a protein $A$ /protein $G$ mixture was performed in order to minimize background signals.

\section{SDS-PAGE and Western}

The aliquots of SPP supernatants were resuspended in sample buffer and separated on 15\% SDS-PAGE. rhDNaseI from CHO cells (Pulmozyme ${ }^{\circledR}$, Roche) served as reference. The gels were blotted onto nitrocellulose membranes and blocked in PBS containing 0.05\% Tween 20 and 5\% skimmed milk (PBS-TM). The anti-rhDNaseI was used in a 1:500 dilution in PBS-TM. After washing with PBS/T and application of HRP-conjugated anti rabbit serum the blots were developed using chemiluminescence.

\section{Immunoprecipitation of DNase I from $\mathrm{T}$. thermophila supernatants}

Anti DNase serum was coupled to cyanogen bromide activated Sepharose $4 \mathrm{~B}$ according to the manufacturer's instructions. T. thermophila supernatants were applied to the column. After washing with PBS, bound protein was eluted with $0.1 \mathrm{M} \mathrm{HCl-glycin} \mathrm{pH} 2.8$ and neutralized with 2 M Tris.

\section{DNase I activity assay}

The methyl green based DNase activity assay was performed as already published [36]. Samples were incubated at $37^{\circ} \mathrm{C}$ for $24 \mathrm{~h}$ on a microtiter plate. Absorbance was measured at $620 \mathrm{~nm}$.

Calibration of the assay was achieved by different amounts of defined DNase I Units of Pulmozyme ${ }^{\circledast}$ from Roche (CHO derived) in each experiment and linear regression. These results combined with semi-quantitative western blotting were used to calculate the specific activity of expressed DNase I.

\section{Purification of rhDNase I and $\mathrm{N}$-glycan analysis of rhDNase I from recombinant $\mathrm{T}$. thermophila supernatants}

Purification of the rhDNase I was performed with slight modifications as described previously [35]. Band-shift assay: We performed an immunoprecipitation as described above. An aliquot of the IP sample was de-glycosylated by applying N-glycosidaseF (Roche, Germany) according to the manufacturer's instructions. The de-glyc- osylation of rhDNaseI was used to control the glycosylation assay. Concanavalin pull down assay: We used ConA coupled to Sepharose 4B beads. The beads were washed and resuspended in PBS in order to prepare a 50\% slurry. $200 \mu \mathrm{l}$ of the $50 \%$ slurry was added to cell-free supernatant. The beads were incubated for $3 \mathrm{~h}$ under rotation at room temperature to allow the Con A beads to bind to the glycosylated proteins. After that, Con A beads were collected by centrifugation ( $2 \mathrm{~min}, 1000 \times \mathrm{g}$ at $4^{\circ} \mathrm{C}$ ) and subsequently washed in PBS with $1 \%$ TritonX-100. All samples were analysed by SDS-PAGE and Western blot. DSA-FACE analysis of N-glycans: Purified recombinant DNaseI from transformed T. thermophila and rhDNase I from $\mathrm{CHO}$ cells were analysed by the DSA-FACE N-glycan analysis method, as previously described [32]. Enzymatic digestions ( $T$. reesei alpha 1,2-mannosidase, jack bean mannosidase and Arthrobacter ureafaciens alpha 2,3/6/8/9sialidase) were done in $20 \mathrm{mM} \mathrm{NaAc}$ pH 5.5 for $16 \mathrm{~h}$.

\section{Authors' contributions}

TW participated in the cloning, western blots and the Con A pulldown assays, carried out conception and manuscript drafting. LH carried out the immunoprecipitation, purification and DNase I assays and participated in conception and manuscript drafting. UB participated in the cloning of expression constructs and performed the transformation of the Ciliates. NN cloned expression constructs. IA was responsible for fermentations and media compositions. WL did the DSA-FACE analysis. RC made the conception for the N-glycan profiling. AT helped to draft the manuscript. MWWH conceived of the study and participated in its design and coordination. All authors read and approved the final manuscript.

\section{Acknowledgements}

We are grateful to Leif Rasmussen (Odense University, Denmark) and Michael Fricker (University of Cambridge, UK) for critical reading the manuscript and Jan Rossdorf, Angelika Kronenfeld and Linsay Huebers for excellent technical assistance.

\section{References}

I. Turkewitz AP, Orias E, Kapler G: Functional genomics: the coming of age for Tetrahymena thermophila. Trends Genet 2002, 18:35-40.

2. Orias $\mathrm{E}:$ Toward sequencing the Tetrahymena genome: exploiting the gift of nuclear dimorphism. J Eukaryot Microbiol 2000, 47:328-333.

3. Yao MC, Fuller P, Xi X: Programmed DNA deletion as an RNAguided system of genome defense. Science 2003, 300: $1581-1584$

4. Mochizuki K, Gorovsky MA: Small RNAs in genome rearrangement in Tetrahymena. Curr Opin Genet Dev 2004, I 4: I8I-I87.

5. Cech TR, Zaug AJ, Grabowski PJ: In vitro splicing of the ribosomal RNA precursor of Tetrahymena: involvement of a guanosine nucleotide in the excision of the intervening sequence. Cell I98I, 27:487-496.

6. Gibbons IR, A.J R: Dynein: a protein with adenosine triphosphatase activity from cilia. Science 1965, 149:424-426.

7. Blackburn EH, Gall JG: A tandemly repeated sequence at the termini of the extrachromosomal ribosomal RNA genes in Tetrahymena. J Mol Biol I978, I 20:33-53. 
8. Greider CW, Blackburn EH: Identification of a specific telomere terminal transferase activity in Tetrahymena extracts. Cell 1985, 43:405-4I3.

9. Brownell JE, Zhou J, Ranalli T, Kobayashi R, Edmondson DG, Roth SY, Allis CD: Tetrahymena histone acetyltransferase A: a homolog to yeast $\mathrm{Gcn} 5 p$ linking histone acetylation to gene activation. Cell I996, 84:843-85I.

10. Gaertig J, Gao Y, Tishgarten T, Clark TG, Dickerson HW: Surface display of a parasite antigen in the ciliate Tetrahymena thermophila. Nat Biotechnol 1999, 17:462-465.

II. Clark TG, Gao Y, Gaertig J, Wang X, Cheng G: The I-antigens of Ichthyophthirius multifiliis are GPI-anchored proteins. I Eukaryot Microbiol 200I, 48:332-337.

12. Peterson DS, Gao Y, Asokan K, Gaertig J: The circumsporozoite protein of Plasmodium falciparum is expressed and localized to the cell surface in the free-living ciliate Tetrahymena thermophila. Mol Biochem Parasitol 2002, I 22: I 19-1 26.

13. Larsen LK, Andreasen PH, Dreisig H, Palm L, Nielsen H, Engberg J, Kristiansen $\mathrm{K}$ : Cloning and characterization of the gene encoding the highly expressed ribosomal protein 13 of the ciliated protozoan Tetrahymena thermophila. Evidence for differential codon usage in highly expressed genes. Cell Biol Int 1999, 23:55I-560.

14. Saul A, Battistutta D: Codon usage in Plasmodium falciparum. Mol Biochem Parasitol 1988, 27:35-42.

15. Wuitschick JD, Karrer KM: Codon usage in Tetrahymena thermophila. Methods Cell Biol 2000, 62:565-568.

16. Wuitschick JD, Karrer KM: Analysis of genomic G + C content codon usage, initiator codon context and translation termination sites in Tetrahymena thermophila. J Eukaryot Microbiol 1999, 46:239-247.

17. The Institute for Genomic Research. [ http://www.tigr.org ].

18. Kiy T, Tiedtke A: Continuous high-cell-density fermentation of the ciliated protozoon Tetrahymena in a perfused bioreactor. Appl Microbiol Biotechnol 1992, 38: |4I-I46.

19. Kiy T, Tiedtke A: Effects of immobilization on growth, morphology, and DNA content of the ciliated protozoon Tetrahymena thermophila. FEMS Microbiol Lett 1993, 106: I 17-122.

20. Wheatley DN, Rasmussen L, Tiedtke A: Tetrahymena: a model for growth, cell cycle and nutritional studies, with biotechnological potential. Bioessays 1994, 16:367-372.

21. Price PA, Stein WH, Moore S: Effect of divalent cations on the reduction and re-formation of the disulfide bonds of deoxyribonuclease. J Biol Chem 1969, 244:929-932.

22. Lauwers A, Scharpe S: Deoxyribonuclease I. In Pharmaceutica Enzymes Edited by: Swarbrick J. New York, Marcell Dekker Inc.; 1997:285-304

23. Hartmann M, Guberman A, Florin-Christensen M, Tiedtke A Screening for and characterization of phospholipase AI hypersecretory mutants of Tetrahymena thermophila. Appl Microbiol Biotechnol 2000, 54:390-396.

24. Kiy T, Vosskuhler C, Rasmussen L, Tiedtke A: Three pools of lysosomal enzymes in Tetrahymena thermophila. Exp Cell Res 1993, 205:286-292

25. Bendtsen JD, Nielsen H, von HG, Brunak S: Improved prediction of signal peptides: SignalP 3.0. J Mol Biol 2004, 340:783-795.

26. Gaertig J, Gu L, Hai B, Gorovsky MA: High frequency vectormediated transformation and gene replacement in Tetrahymena. Nucleic Acids Res 1994, 22:539I-5398.

27. Bradshaw NR, Chilcoat ND, Verbsky JW, Turkewitz AP: Proprotein processing within secretory dense core granules of Tetrahymena thermophila. J Biol Chem 2003, 278:4087-4095.

28. Shang Y, Song X, Bowen J, Corstanje R, Gao Y, Gaertig J, Gorovsky MA: A robust inducible-repressible promoter greatly facilitates gene knockouts, conditional expression, and overexpression of homologous and heterologous genes in Tetrahymena thermophila. Proc Natl Acad Sci U S A 2002 99:3734-3739.

29. Hellenbroich D, Valley U, Ryll T, Wagner R, Tekkanat N, Kessler W, Ross A, Deckwer WD: Cultivation of Tetrahymena thermophila in a $1.5-\mathrm{m} 3$ airlift bioreactor. Appl Microbiol Biotechnol 1999, $51: 447-455$

30. Becker B, Rusing M: Structure of $\mathbf{N}$-glycosidic carbohydrates of secretory proteins of Tetrahymena thermophila. J Eukaryot Microbiol 2003, 50:235-239.
31. Taniguchi T, Mizuochi T, Banno Y, Nozawa Y, Kobata A: Carbohydrates of lysosomal enzymes secreted by Tetrahymena pyriformis. J Biol Chem 1985, 260:13941-13946.

32. Callewaert N, Geysens S, Molemans F, Contreras R: Ultrasensitive profiling and sequencing of $\mathbf{N}$-linked oligosaccharides using standard DNA-sequencing equipment. Glycobiology 200I, I I:275-28|.

33. Macauley-Patrick S, Fazenda ML, McNeil B, Harvey LM: Heterologous protein production using the Pichia pastoris expression system. Yeast 2005, 22:249-270.

34. Vervecken W, Kaigorodov V, Callewaert N, Geysens S, De Vusser K, Contreras R: In vivo synthesis of mammalian-like, hybrid-type N-glycans in Pichia pastoris. Appl Environ Microbiol 2004, 70:2639-2646.

35. Takeshita H, Yasuda T, Nakazato E, Nakajima T, Mori S, Mogi K, Kaneko $Y$, lida R, Kishi K: Use of human recombinant DNase I expressed in COS-7 cells as an immunogen to produce a specific anti-DNase I antibody. Exp Clin Immunogenet 200I, I 8:226-232.

36. Sinicropi D, Baker DL, Prince WS, Shiffer K, Shak S: Colorimetric determination of DNase I activity with a DNA-methyl green substrate. Anal Biochem 1994, 222:35I-358.

Publish with Biomed Central and every scientist can read your work free of charge

"BioMed Central will be the most significant development for disseminating the results of biomedical research in our lifetime. "

Sir Paul Nurse, Cancer Research UK

Your research papers will be:

- available free of charge to the entire biomedical community

- peer reviewed and published immediately upon acceptance

- cited in PubMed and archived on PubMed Central

- yours - you keep the copyright 